\title{
Analisa Pembagian Penggunaan Bandwidht Untuk Jaringan Internet Pelanggan Mnc Play Area Jakarta Dengan Menggunakan Teknologi Link Aggregation Dan Load Balance
}

\author{
Eka Permatasari*1, Rushendra ${ }^{2}$ \\ Teknik Informatika, Fakultas Ilmu Komputer, Universitas Mercu Buana, Jakarta Barat, \\ Indonesia 11650 \\ e-mail: ${ }^{* 1}$ 41517120074@ @student.mercubuana.ac.id, ${ }^{2}$ rushendra@ mercubuana.ac.id
}

\begin{abstract}
Abstrak
Dalam sebuah perusahaan penyedia layanan jaringan internet, di tuntut untuk memiliki kulitas jaringan high availability dan high reliability. Dalam mendukung kualifikasi jaringan internet terbaik maka salah satunya perlu menjaga kestabilan bandwidth internet pelanggan. Salah satunya menjaga kepadatan traffic data pada jaringan internet. Congestion merupakan pengumpulan paket data yang melebihi kapasitas bandwidth yang tersedia padasebuah link, hal ini memberikan dampak penurunan kinerja jaringan internet. Permasalahan di atas dapat di selesaikan salah satunya dengan menerapkan penggunaan metode link aggregation dan teknologi load balance. Pada penelitian ini penulis menerapkan metode link aggregation yang digunakan dalam merancang redundancy link dan load balance dalam membuat skema membagi traffic untuk penyeimbang beban berdasarkan src address dan src port, serta dst address dan $d s t$ port. Dari hasil pengujian penggunaan link aggregation dan load balance pada penenlitian ini dapat membantu menjaga kestabilan throughput dengan nilai pengukuran sebesar 10GB dengan standart MTU (Maximum Transmission Unit) yang menandakan hasil test pengukuran paket data terbesar yang dapat di transmisikan melalui sebuah jaringan.
\end{abstract}

Keyword : link aggregation, load balance, congestion, MTU

\section{PENDAHULUAN}

Perusahaan bergerak secara meluas dengan di dorong oleh kebutuhan layanan nirkabel saat ini ${ }^{1}$ maka sebagai penyedia jasa layanan telekomunikasi jaringan internet, akan di tuntut untuk memberikan pelayanan jaringan yang berkualitas high availability, high realibility, kecepatan jaringan yang tinggi dan mempunyai ruang penyimpanan dengan kapasitas yang besar ${ }^{2}$. Perusahaan bergerak secara meluas Konektivitas pada jaringan internet pelanggan dapat terganggu karna adanya permasalahan yang muncul, salah satunya ada pada peningkatan dari jumlah pengguna jaringan yang signifikan dimana penggunaan jaringan melebihi batas kapasitas bandwidth yang di sediakan oleh perusahaan. Dampak dari hal tersebut dapat membuat overload dan menurunkan performansi jaringan. Atau adanya gangguan yang menyebabkan salah satu link down sehingga perlu adanyany link yang lain untuk membackup hal tersebut ${ }^{3}$.

Jurnal Ilmiah Al QALAM, Vol. 15, No. 2, Juli-Desember 2021 
Eka Permatasari, Rushendra : Analisa Pembagian Bandwidht Untuk Jaringan Internet Pelanggan Mnc Play Area Jakarta Dengan Menggunakan Teknologi Link Aggregation Dan Load Balance

Untuk dapat menangani hal tersebut salah satunya dengan penambahan ketersediaan kapasitas bandwidth. Namun untuk menjaga ketersediaan layanan tersebut hanya dengan menggunakan 1 interface saja tidak cukup, jika terjadi down pada interface tersebut maka koneksi akan terputus sehingga menggangu pengguna jaringan internet. Dalam mengatasi permasalahan ini, beberapa penelitian menerapkan penggunaan dengan metode Link aggregation dan load balance. Metode Link aggregation mampu menggabungan link fisik dengan link logic dalam meningkatkan kapasitas bandwidth serta meningkatkan kapasitas dari yang di sediakan ${ }^{4}$. Metode load balance berkerja dalam mendistribusikan serta menyeimbangkan beban traffic yang di dapat dari 2 hingga 8 jalur jaringan pada 1 link fisik, hal ini bisa untuk mengatasi jika adanya penumpukan beban traffic pada 1 link (overload) namun traffic pada salah satu jalur lainnya tetap dapat berjalan secara optimal ${ }^{5}$.

Penulis akan melakuakn penelitian dengan menganalisa terkait penggunaan bandwidth internet pelanggan yang sering terjadi gangguan akibat penumpukkan data pada salah satu jalur ${ }^{6}$ (congestion) yang berdampak pada penurunan kinerja internet, dengan menggunakan metode link aggregation dan load balance yang di tunjukan untuk mencegah adanya keterlambatan pada pengiriman data karna adanya pengumpulan paket data berlebih yang menyebabkan overload karna adanya penumpukkan paket pada satu jalur saja serta dapat membantu saat terjadinya down karena salah satu jalur jaringan terputus ${ }^{7}$.

Penggunaan metode link aggregation bertugas untuk melakukan pengelolahan dan mendistribusikan aktivitas pada beberapa link untuk menangani traffic berlebih serta dapat menaikkan kecepatan koneksi pada perangkat router ataupun switch. Jika terdapat adanya kerusakan pada jalur jaringan maka secara otomatis system akan berganti ke link yang aktif pada link group yang sama dalam menjaga sistem. Dimana untuk pembagian bandwidth internet pada setiap link menggunakan metode load balance untuk menyeimbangkan beban traffic pada setiap jalur.

\section{METODE PENELITIAN}

Penulis menerapkan penelitian komparatif kualitatif menggunakan studi kasus yang menjadi analisa penelitian. Penulis menggunakan metode perancangan jaringan PPDIOO (Prepare, Plan, Design, Implement, Operate and Optimize). Merupakan metode yang di kembangkan oleh Cisco sebagai bentuk untuk mendukung jaringan berkembang ${ }^{8}$.

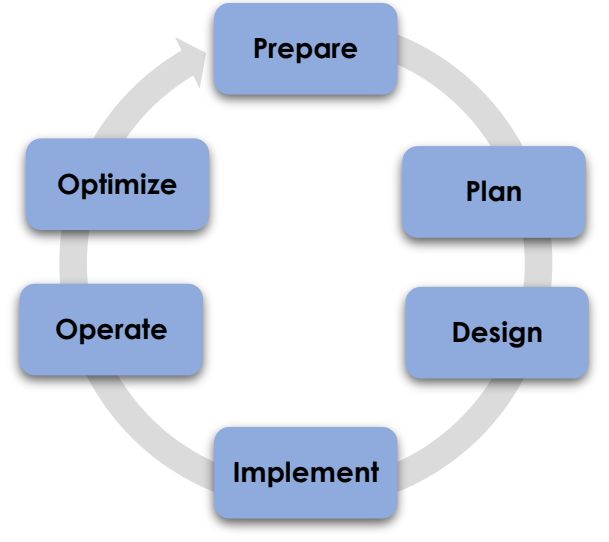

Jurnal Ilmiah Al QALAM, Vol. 15, No. 2, Juli-Desember 2021 
Eka Permatasari, Rushendra : Analisa Pembagian Bandwidht Untuk Jaringan Internet Pelanggan Mnc Play Area Jakarta Dengan Menggunakan Teknologi Link Aggregation Dan Load Balance

\section{Gambar 1 Metode PPDIOO}

\section{A. Prepare}

Prepare yaitu tahapan awal pada penelitian dalam melakukan rencana kerja yang berhubungan dalam analisa pokok pembahasan penelitian, seperti masalah yang dihadapi, topologi jaringan yang akan dibangun, dan kebutuhan dari sisi hardware maupun software? .

Data perangkat serta spesifikasinya dirangkum pada Tabel 1 dan Tabel 2.

Tabel 1. Perangkat Keras (Hardware)

\begin{tabular}{|c|c|c|}
\hline No & Perangkat & Deskripsi \\
\hline 1 & Router & ASR9k \\
\hline 2 & Switch & ZXR10 5960-72DL \\
\hline 3 & Laptop & Lenovo, Intel Core i3, RAM 8GB \\
\hline 4 & Tester & EXFO MAX-960G Tester \\
\hline
\end{tabular}

Tabel 2. Perangkat Lunak (Software)

\begin{tabular}{|c|c|c|}
\hline No & Perangkat & Deskripsi \\
\hline 1 & Sistem Operasi Router & SecureCRT \\
\hline
\end{tabular}

\section{B. Plan}

Plan (perencanaan) merupakan tahapan perancangan jaringan berdasarkan tujuan, fasilitas, dan kebutuhan pelanggan ${ }^{9}$. Berikut flowchart diagram dari tahapan penelitian.

Jurnal Ilmiah Al QALAM, Vol. 15, No. 2, Juli-Desember 2021 
Eka Permatasari, Rushendra : Analisa Pembagian Bandwidht Untuk Jaringan Internet Pelanggan Mnc Play Area Jakarta Dengan Menggunakan Teknologi Link Aggregation Dan Load Balance

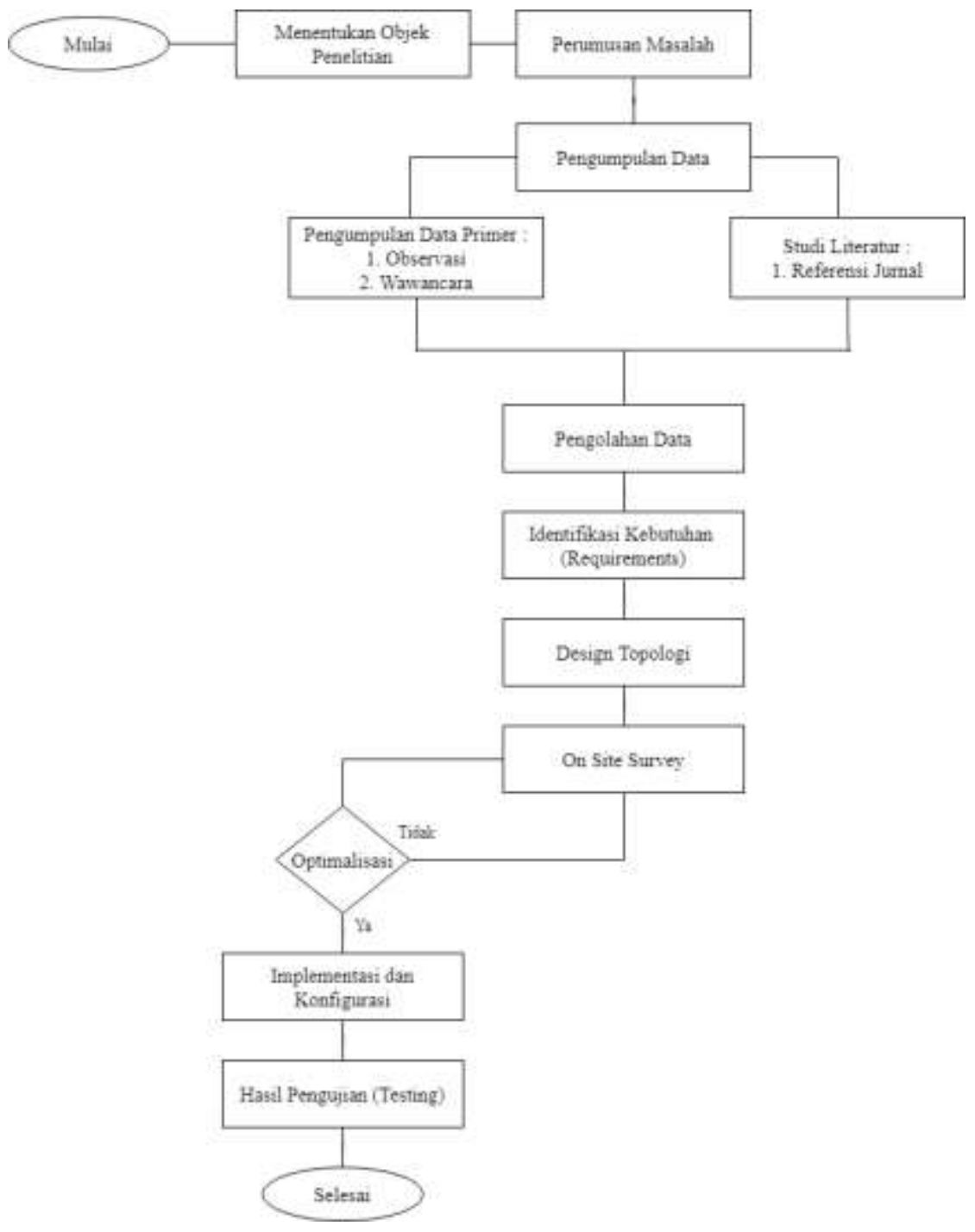

\section{Design}

\section{Gambar 2 Flowchart Perancangan Penelitian.}

Tahapan ini membuat jaringan berdasarkan persyaratan teknis dan perencanaan yang telah dilakukan. Pada gambar 3 terdapat topologi awal jaringan, dimana pada topologi awal tidak menggunakan metode link aggregation dan load balance. Dapat di lihat pada BRAS ke switch hanya memiliki 1 link saja. Hal ini menyebabkan terjadinya traffic yang lewat melebihi kapasitas yang disediakan yang menyebabkan overload bandwidth dan penurunan performa jaringan. Jika satu port GE untuk $700 \mathrm{Mbps}$, namun dikemudian hari ada kebutuhan akses pelanggan melebihi bandwidth yang tersedia. Dengan kondisi tersebut maka akan terdapat packet drop yang menyebabkan packet loss. Berikut topologi jaringan awal yang diajukan dengan menggunakan metode link aggregate dan Load Balance.

Jurnal Ilmiah Al QALAM, Vol. 15, No. 2, Juli-Desember 2021 
Eka Permatasari, Rushendra : Analisa Pembagian Bandwidht Untuk Jaringan Internet Pelanggan Mnc Play Area Jakarta Dengan Menggunakan Teknologi Link Aggregation Dan Load Balance

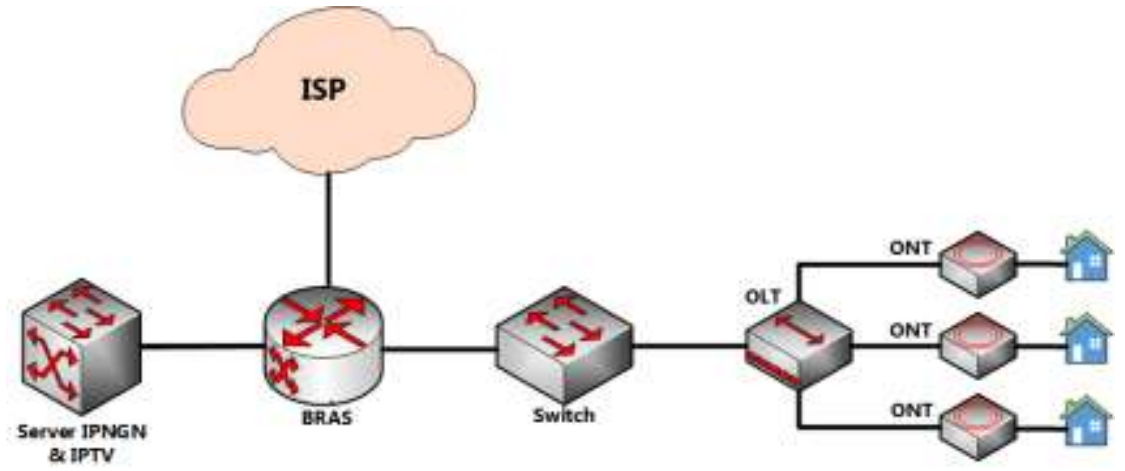

Gambar 3 Topologi Jaringan Awal.

Pada gambar 4 perangkat BRAS dan switch yang sudah di implementasikan menggunakan metode link aggregation dan load balance. Pada BRAS dan switch terdapat 2 port link yang artinya sudah aktif redundancy link (Link Aggregation). Dimana adanya link sebagai alternatif untuk membantu dalam menambah ketersediaan jaringan, nantinya jika salah satu link terjadi down, maka akan ada link jaringan lainnya untuk dapat dilewati sebagai pengiriman data tanpa mempengaruhi konektivitas jaringan.

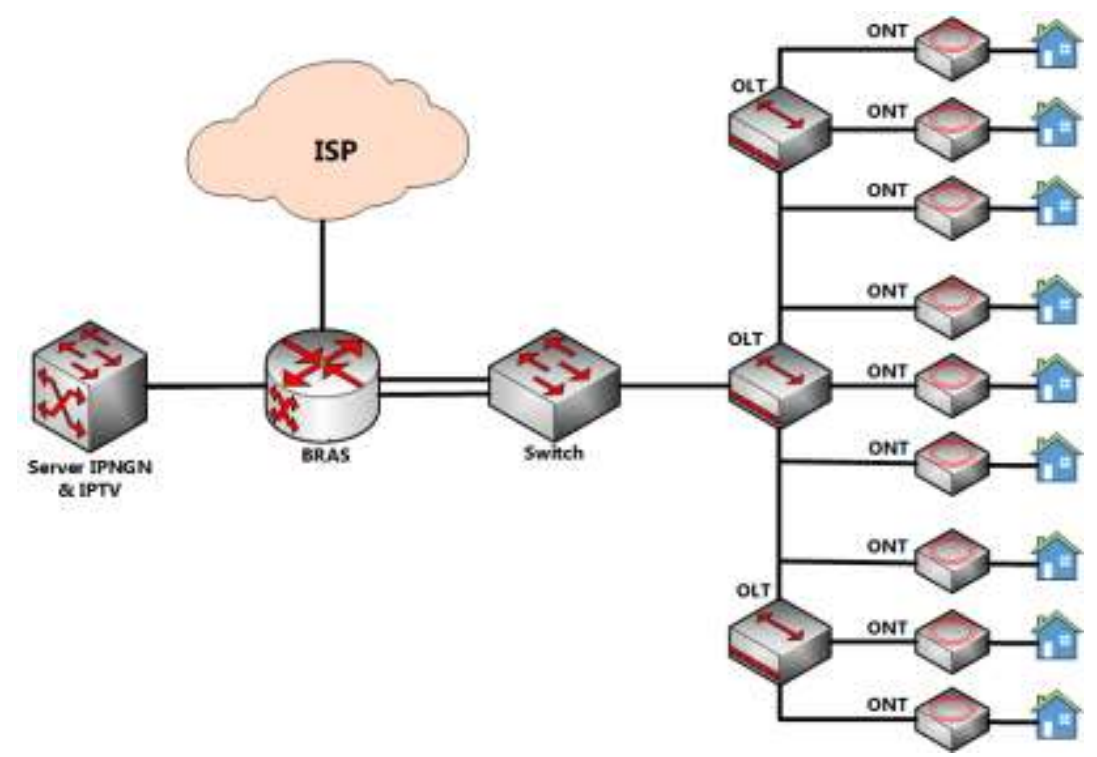

Gambar 4 Rancangan Topologi Jaringan

\section{Implementation}

Pada tahap ini melakukan implementasi untuk instalasi dan konfigurasi, sesuai spesifikasi desain yang telah dibuat. Setelah melakukan observasi di lapangan oleh teknisi, di lanjutkan dengan melakukan implementasi. Pada tahap ini melakukan konfigurasi menggunakan metode link aggregation pada perangkat switch dan router, setelah itu di lanjut ke proses konfigurasi metode Load Balance pada perangkat switch.

\section{E. Operate}

Jurnal Ilmiah Al QALAM, Vol. 15, No. 2, Juli-Desember 2021 
Eka Permatasari, Rushendra : Analisa Pembagian Bandwidht Untuk Jaringan Internet Pelanggan Mnc Play Area Jakarta Dengan Menggunakan Teknologi Link Aggregation Dan Load Balance

Pada tahap ini melakukan percobaan pengetesan untuk konfigurasi link aggregate dan Load Balance yang telah diimplementasikan sebelumnya. Pengujian link aggregation dilakukan pada perangkat router dengan melihat apakah link aggregation sudah terhubung atau belum dan melalukan pengukuran bandwidth. Pengukuran dilakukan nenggunakan perangkat EXFO MAX-960G Tester. Serta pengujian Load Balance untuk melihat apakah bandwidth sudah terbagi sesuai dengan kebutuhan atau belum.

\section{Throughput}

Throughput ialah kecepatan pada proses pengiriman data, data ini diukur dalam satuan bit per second (BPS) yang berdasarkan pada jumlah total data yang sukses sampai ke tujuan ${ }^{10}$. Berikut adalah cara menghitung Throughput:

$$
\text { Throughput }=\frac{\text { Jumlah paket yang diterima }}{\text { Jumlah waktu pengiriman }}
$$

Throughput diperoleh melalui persamaan (1) dan kategori yang diukur berdasarkan standar TIPHON pada table 3 .

\begin{tabular}{cc}
\hline Kategori Throughput & Throughput (bps) \\
\hline Sangat Bagus & 100 \\
Bagus & 75 \\
Sedang & 50 \\
Buruk & $<25$ \\
\hline
\end{tabular}

Tabel 3. Parameter throughput

\section{Latency/Delay}

Latency/Delay ialah waktu yang digunakan dalam melakukan proses pengiriman data atau informasi hingga sampai ketempat tujuan pada sebuah jaringan ${ }^{10}$. Jika semakin tinggi nilai delay yang didapat maka semakin buruk kualitas jaringan tersebut. Berikut adalah cara menghitung Delay:

$$
\text { Delay }=\frac{\text { Total delay }}{\text { Total paket yang diterima }}
$$

Persamaan (2), nilai delay didapat dari lamanya waktu yang dibutuhkan dibagi dengan total paket yang diterima dengan kategori delay yang diukur berdasarkan standar TIPHON pada tabel 4

\begin{tabular}{cc}
\hline Kategori Delay/Latency & Delay/Latency \\
\hline Sangat Bagus & $<150 \mathrm{~ms}$ \\
Bagus & $150 \mathrm{~ms} \mathrm{~s} / \mathrm{d} 300 \mathrm{~ms}$ \\
Sedang & $300 \mathrm{~ms} \mathrm{~s} / \mathrm{d} 450 \mathrm{~ms}$ \\
Buruk & $>450 \mathrm{~ms}$ \\
\hline
\end{tabular}

Tabel 4. Parameter Delay

\section{Jitter}

Jurnal Ilmiah Al QALAM, Vol. 15, No. 2, Juli-Desember 2021 
Eka Permatasari, Rushendra : Analisa Pembagian Bandwidht Untuk Jaringan Internet Pelanggan Mnc Play Area Jakarta Dengan Menggunakan Teknologi Link Aggregation Dan Load Balance

Jitter merupakan sebuah variasi dari delay namun dengan perbedaan pada jarak waktu kedatangan pada setiap paket ke terminal tujuan ${ }^{10}$. Nilai jitter yang direkomendasikan oleh ITU-T Y.1541 adalah dibawah $50 \mathrm{~ms}$. Berikut adalah cara menghitung Jitter :

$$
\text { Jitter }=\frac{\text { Total } \text { variasi Delay }}{\text { Total paket yang diterima }-1}
$$

Persamaan (3), nilai jitter didapat dari Total vasriasi delay dibagi dengan total paket yang diterima di kurang 1 dengan kategori jitter yang diukur berdasarkan standar TIPHON pada tabel 5

\begin{tabular}{cc}
\hline Kategori Jitter & Jitter \\
\hline Sangat Bagus & $0 \mathrm{~ms}$ \\
Bagus & $0 \mathrm{~ms} \mathrm{~s} / \mathrm{d} 75 \mathrm{~ms}$ \\
Sedang & $75 \mathrm{~ms} \mathrm{~s} / \mathrm{d} 125 \mathrm{~ms}$ \\
Buruk & $125 \mathrm{~ms} \mathrm{~s} / \mathrm{d} 225 \mathrm{~ms}$ \\
\hline
\end{tabular}

Tabel 5. Parameter Jitter

\section{F. Optimize}

Pada tahap ini di dapat hasil pengujian dari penggabungan interface pada perangkat jaringan router Cisco dapat meningkatkan kecepatan data dan jumlah paket yang dapat di lewatkan. Berdasarkan hasil pengujian untuk konfigurasi link aggregation dan Load Balance

\section{HASIL DAN PEMBAHASAN}

Pada penelitian ini setelah melalui tahapan perancangan jaringan dengan metode PPDIOO, konfigurasi jaringan menggunakan metode link aggregation dan load balance, pengecekkan pelanggan yang sudah bisa menggunakan internet melalui perangkat ONT dan testing bandwidth yang bisa didapat pada setiap link, dari hasil testing ini di dapat nilai delay, throughput dan jitter.

\section{A. Link Aggregation}

Setelah melakukan konfigurasi melalui secureCRT menggunakan metode link aggregation, maka link pada jaringan akan mengalami peningkatan throughput serta mengurangi terjadinya redundancy pada link ${ }^{4}$. Metode link aggregation akan secara otomatis mengganti link fisik dengan link logic ${ }^{5}$ jika terdapat kegagalan dalam proses kerjanya. 
Eka Permatasari, Rushendra : Analisa Pembagian Bandwidht Untuk Jaringan Internet Pelanggan Mnc Play Area Jakarta Dengan Menggunakan Teknologi Link Aggregation Dan Load Balance

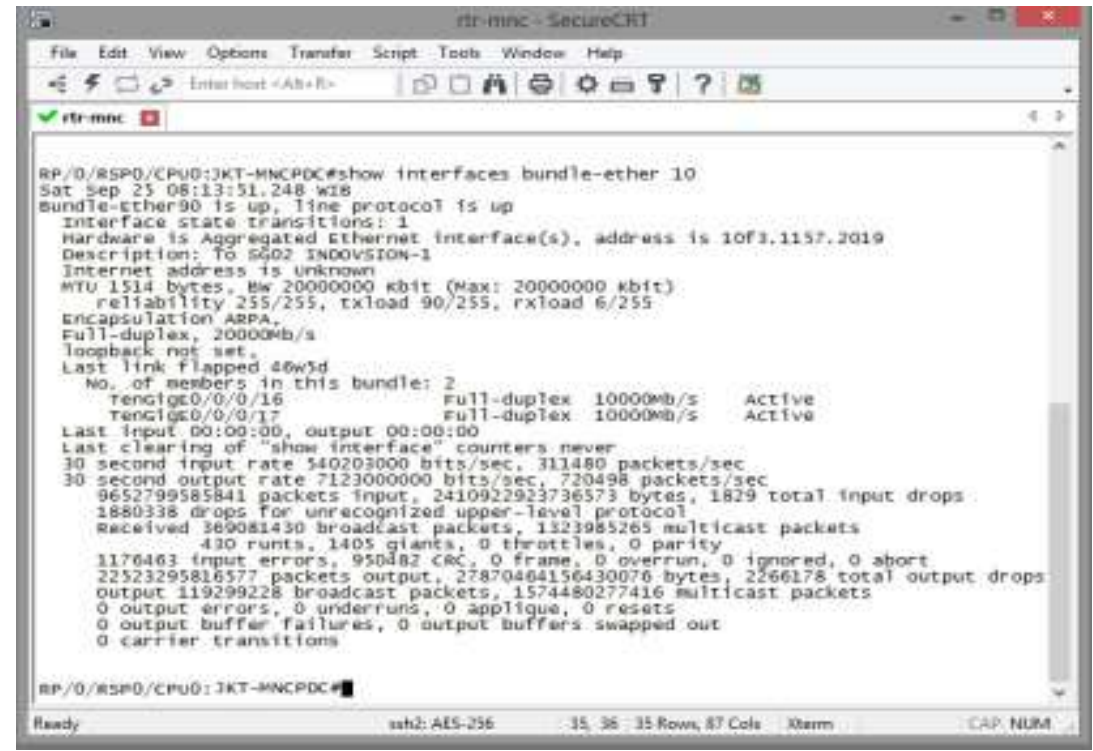

Gambar 5 Link Aggregation Aktif

Pada gambar 5 menunjukan metode link aggregation yang sudah terimplementasi yaitu 2 port link logic yang nantinya akan mencegah keterlambatan pengiriman data, dan membantu mencegah terjadinya overload pada salah satu link saja karena adanya beban kerja jaringan yang menumpuk ${ }^{5}$.

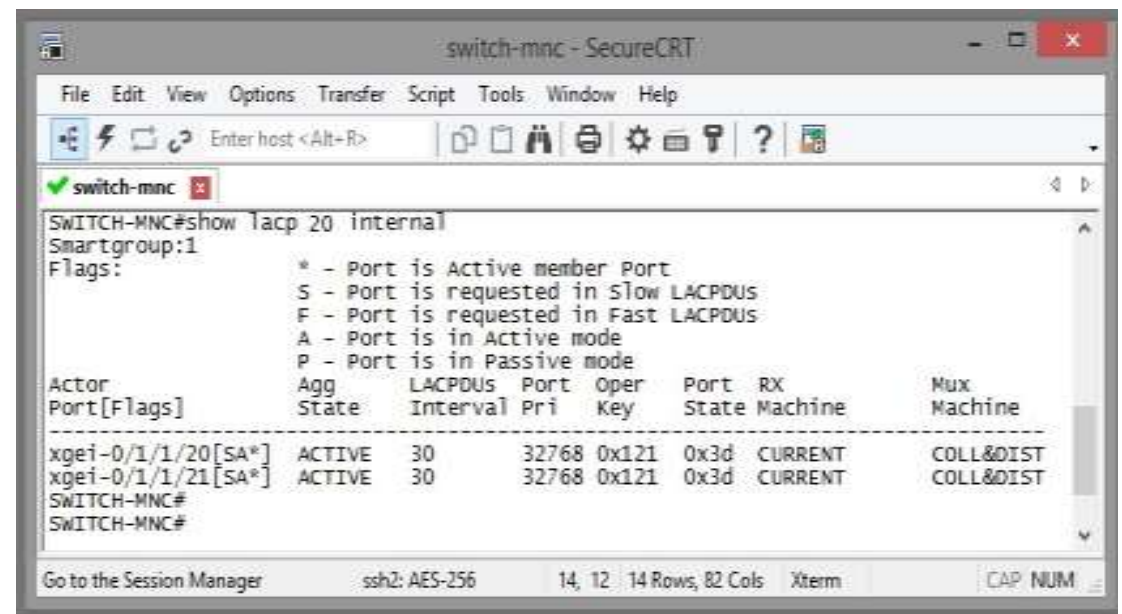

Gambar 6 Link Aggregation

Pada gambar 6 menandakan setelah link aggregation siap maka proses selanjutnta dapat di integrasikan ke perangkat.

\section{B. Load Balance}

Setelah link aggregation sudah aktif pada setiap link fisik, di lanjutkan dengan mengimplementasikan metode load balance. Metode load balance digunakan untuk mendistribusikan dan membagi beban trafik yang ada pada link ke 2 jalur atau lebih secara merata untuk menghindari jika terjadi overload pada salah satu link ${ }^{11}$. Cara

Jurnal Ilmiah Al QALAM, Vol. 15, No. 2, Juli-Desember 2021 
Eka Permatasari, Rushendra : Analisa Pembagian Bandwidht Untuk Jaringan Internet Pelanggan Mnc Play Area Jakarta Dengan Menggunakan Teknologi Link Aggregation Dan Load Balance

kerja metode load balance yaitu dengan membagi beban traffic ke setiap link yang aktif dengan sama rata.

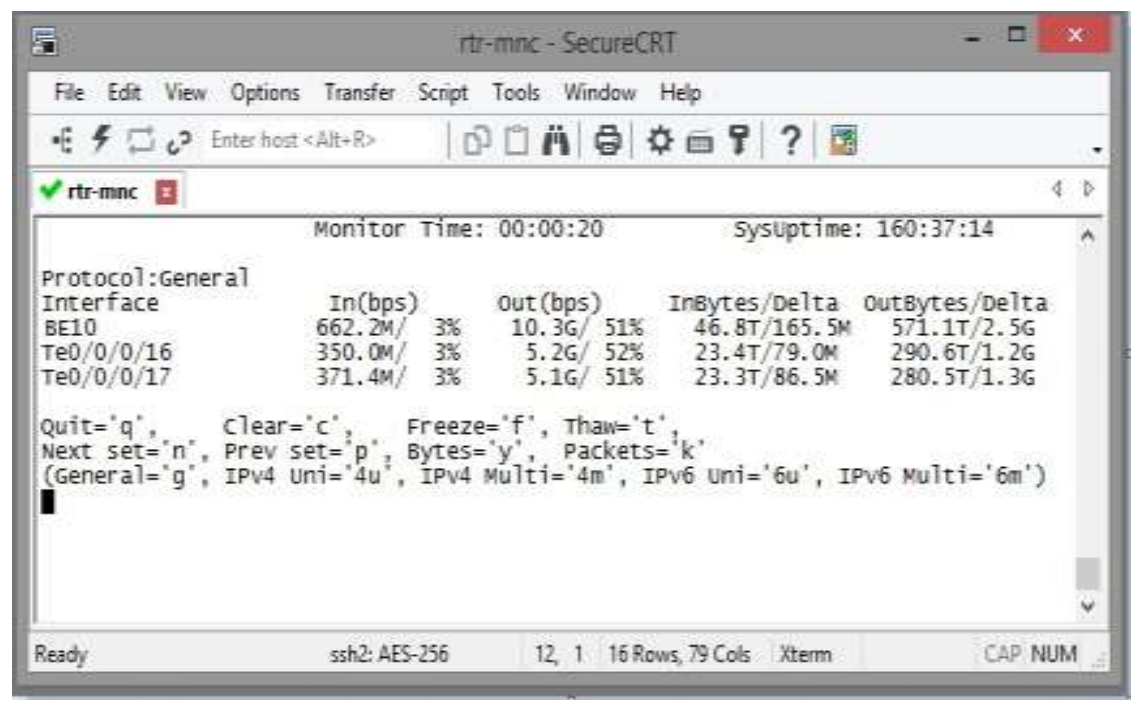

Gambar 7 Metode Load Balance

Pada gambar 6 menunjukan bahwa metode load balance berhasil membagi beban secara merata pada setiap link yang ada yaitu terdapat beban traffic sebesar 662 Mbps, load balance berkerja dengan membagi setiap masing - masing link yang aktif menjadi $>350$ Mbps - 371 Mbps.

\section{Analisa QoS (Quality Of Service)}

Pada tabel 9 penulis membuat table hasil pengujian pada penelitian yang dilakukan serta menghitung nilai rata-rata. Hasil nilai tersebut akan mengacu pada standar angka THIPON.

\begin{tabular}{|c|c|c|c|}
\hline \multicolumn{4}{|c|}{ Pengujian Link Aggregation dan Load Balance } \\
\hline Parameter QOS & Pengukuran & Index & Kategori \\
\hline Delay/Latency (ms) & 0,652 & 4 & \multirow{3}{*}{ Bagus } \\
\hline Jitter (ms) & 0,7 & 4 & \\
\hline $\begin{array}{l}\text { Throughput } \\
\text { (Gbits/sec) }\end{array}$ & 9,87899 & 4 & \\
\hline \multicolumn{2}{|c|}{ Average Informasi Indexs } & 4 & Memuaskan \\
\hline
\end{tabular}

Tabel 6. Hasil Pengujian Qos

Jurnal Ilmiah Al QALAM, Vol. 15, No. 2, Juli-Desember 2021 
Eka Permatasari, Rushendra : Analisa Pembagian Bandwidht Untuk Jaringan Internet Pelanggan Mnc Play Area Jakarta Dengan Menggunakan Teknologi Link Aggregation Dan Load Balance

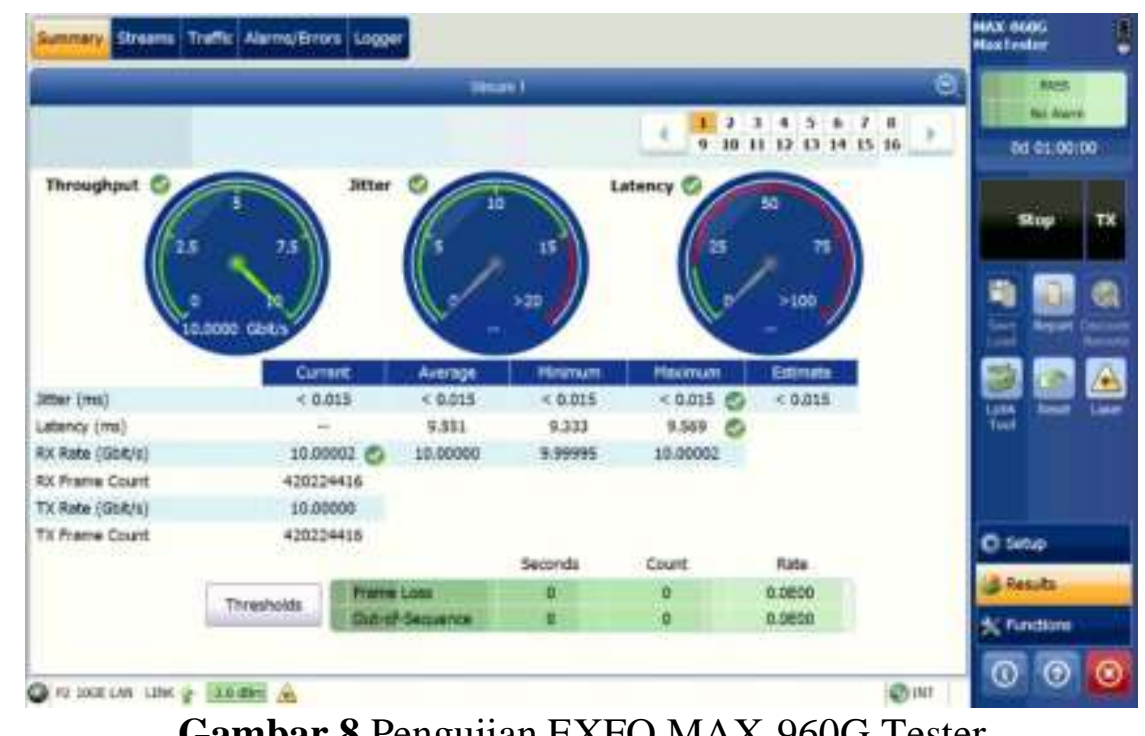

Gambar 8 Pengujian EXFO MAX-960G Tester

Pada tabel 9 dan gambar hasil pengujian dengan data yang di dapat dari aplikasi wireshak maupun dengan pengujian menggunakan perangkat EXFO MAX-960G Tester menunjukan hasil yang tidak berbeda. Hal ini karena sudah terimplementasi metode link aggregation dan load balance dimana mendapatkan hasil nilai yang bagus.

\section{KESIMPULAN}

Hasil dari penelitian dengan menggunakan metode link aggregation dan load balance dapat mengatasi permasalahan penumpukkan paket pada satu jalur saja atau overload yang menyebabkan penurunan kinerja jaringan. Jalur yang sudah aktif agregasi dapat meningkatkan performansi, hal ini karena jalur mampu melewati data secara bersamaan dengan membagi beban traffic pada setiap jalurnya menggunakan metode load balance. Dari analisa QoS dapat disimpulkan bahwa implementasi pembagian bandwidht dengan metode link aggregation dan load balance memiliki performansi yang baik, di lihat dari nilai delay $0,652 \mathrm{~ms}$, nilai jitter $0,7 \mathrm{~ms}$ dan nilai throuhput sebesar 9,8 GB. Hal ini sesuai dengan standarisasi ITU-T dimana nilai $<150 \mathrm{~ms}$ memiliki average informasi index yang bagus. Sehingga dapat di simpulkan bahwa implementasi dengan link aggregation dan load balance mampu menjaga dan memberikan layanan high availability dan high reliability bagi pelanggan.

\section{UCAPAN TERIMA KASIH}

Penulis mengucapkan terima kasih kepada PT MNC Play sebagai pihak yang memfasilitasi penelitian ini dan berbagai pihak yang sudah membantu.

\section{DAFTAR PUSTAKA}

Hidayat R, Rushendra R, Agustina E. Digital beamforming of smart antenna in millimeterwave

Jurnal Ilmiah Al QALAM, Vol. 15, No. 2, Juli-Desember 2021 
Eka Permatasari, Rushendra : Analisa Pembagian Bandwidht Untuk Jaringan Internet Pelanggan Mnc Play Area Jakarta Dengan Menggunakan Teknologi Link Aggregation Dan Load Balance

communication. 2017 Int Conf Broadband Commun Wirel Sensors Powering, BCWSP 2017. 2018;2018-January:1-5. doi:10.1109/BCWSP.2017.8272564

Irawati LD, Hariyani YS, Hadiyoso S. Link Aggregation Control Protocol on Software Defined Network. Int J Electr Comput Eng. 2017;7(5):2706. doi:10.11591/ijece.v7i5.pp2706-2712

Nadzir M, Saharuna Z, Irmawati, Irawan, Nur R. Analisis Performansi Link Aggregation Control Protocol (LACP) Antar Perangkat Switch. Semin Nas Tek Elektro dan Inform 2018. 2018;(October).

Tulloh R. Analisis Performansi Agregasi Link dengan Lacp pada SDN menggunakan RYU sebagai Controller. J Nas Tek Elektro. 2017;6(3):203. doi:10.25077/jnte.v6n3.444.2017

Syaifudin A, Wahyuddin MI, Ningsih S, Informatika PS, Nasional U. Redundancy Link dan Load Balancing Menggunakan Metode EtherChannel LACP dengan InterVLAN Routing. 2020;7(28):137-144.

Khafidin A, Andrasto T, Suryono. Implementation flow control to improve quality of service on computer networks. Indones J Electr Eng Comput Sci. 2019;16(3):1474-1481. doi:10.11591/ijeecs.v16.i3.pp1474-1481

Ramakrishna M, Kodati VK, Gratz P V., Sprintson A. GCA:Global Congestion Awareness for Load Balance in Networks-on-Chip. IEEE Trans Parallel Distrib Syst. 2016;27(7):2022-2035. doi:10.1109/TPDS.2015.2477840

Hernandez L, Jimenez G. Design and validation of a scheme of infrastructure of servers, under the PPDIOO methodology, in the university Institution-ITSA. Adv Intell Syst Comput. 2019;763(January):367379. doi:10.1007/978-3-319-91186-1_38

Fernando MRR, Magaly LMN, Jose CSM. Analysis of Methodologies of Data Networks LAN. Int J Adv Eng Res Sci. 2016;3(9):52-61. doi:10.22161/ijaers/3.9.9

Darojat A, Nurhaida I. Analisa Qos Administrative Distance Static Route Pada Failover Vpn Ipsec. J Ilmu Tek dan Komput. 2019;3(1):11. doi:10.22441/jitkom.2020.v3.i1.002

Saharuna Z, Nur R, Sandi A. Analisis Quality Of Service Jaringan Load Balancing Menggunakan Metode PCC Dan NTH. CESS (Journal Comput Eng Syst Sci. 2020;5(1):131. doi:10.24114/cess.v5i1.14629

Jurnal Ilmiah Al QALAM, Vol. 15, No. 2, Juli-Desember 2021 